\title{
PENGATURAN ULANG PENGISIAN JABATAN KEPALA DAERAH BERDASARKAN PRINSIP KEDAULATAN RAKYAT
}

\author{
Budiyono \\ Bagian HTN Fakultas Hukum Universitas Lampung \\ Email: budiyono.1974@fh.unila.ac.id
}

\begin{abstract}
Abstrak
Sejak diberlakunnya UU No. 32 Tahun 2004 tentang Pemerintahan Daerah pada pertengahan tahun 2005, pengisian jabatan kepala daerah dan wakil kepala daerah dilakukan secara langsung. Terkait dengan UU ini saat ini sedang hangat diperbincangkan tentang pemilihan kepala daerah yang ingin mengembalikan tata cara pemilhan kepala daerah secara langsung menjadi pemilihan kepala daerah oleh DPRD”. Berdasarkan ketentuan Pasal 18 Ayat 4 UUD 1945, Penyelenggaran Pemilukada dapat dilakukan secara langsung atau melalui perwakilan oleh DPRD. Ketentuan ini menyebabkan adanya ketidakpastian dalam menentukan model pengisian jabatan kepala daerah semestinya Undang-Undang Dasar memberikan ketentuan yang tegas seperti tata cara pemilihan presiden dan wakil Presiden secara atau sesuai atau sejalan dengan Pasal 1 Ayat 2 UUD 1945 dimana prinsip kedaulatan rakyat dengan sistem pemilihan langsung.
\end{abstract}

Kata kunci : pengisian jabatan, kepala daerahdan kedaulatan rakyat.

\section{Pendahuluan}

Negara Republik Indonesia sebagai Negara Kesatuan ${ }^{1}$ sebagai Negara Kesatuan maka kedaulatan negara adalah tunggal atau terpusat, tidak tersebar atau terbagi-bagi pada negara-negara bagian seperti dalam negara federal/serikat tetapi Indonesia adalah Negara kesatuan yang menganut desentralisasi ${ }^{2}$ penyelenggaraan pemerintahan.

Salah satu yang menjadi tuntutan agenda reformasi adalah perubahan dalam sistem pemerintahan Daerah di Indonesia. ${ }^{3}$

.${ }^{1}$ Pasal 1 UUD RI 1945

2 M. Laica Marjuki, Berjalan -Jalan di Ranah Hukum: Otonomi Daerah Dalam Perspektif Negara Kesatuan, Penerbit Sekretariat Jenderal \& Kepaniteraan Makamah Konstitusi RI, 2006. Hlm. 159

${ }^{3}$ ada enam tuntutan agenda reformasi (1) amandemen Undang-Undang Dasar 1945;

(2) penghapusan dotrin dwi fungsi ABRI, menurut konstitusi Undang-Undang Dasar 1945 (the higher law of the land) yang menjadi dasar penyelenggaraan pemerintahan baik di pusat maupun di daerah dalam Perubahan Kedua Undang-Undang Dasar 1945 tentang Pemerintahan Daerah dalam Pasal 18. ${ }^{4}$

(3) Penegakan supremasi hukum, penghormatan hak asasi manusia, serta pemberantasan korupsi, kolusi dan nepotisme, (4) desentralisasi dan hubungan yang adil antara pusat dan daerah (otonomi daerah), (5) mewujudkan kebebasan pers, (6) mewujudkan kehidupan demokrasi, Ni'matul Huda yang dikutif oleh Khairul fahmi, Pemilihan umun dan Kedaulatan Rakyat, PT Raja Grafindo Persada, Jakarta, hlm, 1

${ }^{4}$ Pasal 18 UUD Tahun 1945 :

(1) Negara Kesatuan Republik Indonesia dibagi atas daerah-daerah propinsi dan daerah Propinsi itu atas kabupaten dan kota, yang tiap-tiap yang tiap-tiap propinsi, kabupaten, dan kota itu 
Berdasarkan ketentuan Pasal 18 UUD 1945 tersebut terdapat tiga macam organ sebagai subyek hukum pemerintahan daerah yaitu : 1 . Pemerintahan Daerah, 2. Kepala Pemerintah Daerah yang dapat disebut gubernur, bupati, ataupun walikota, 3. DPR Daerah. ${ }^{5}$

Operasionalisasi Pasal 18 tersebut dibentuklah aturan lebih lanjut mengenai pemerintah daerah yakni Undang-Undang Nomor 22 Tahun 1999 kemudian di ganti dengan Undang-Undang 32 Tahun 2004 tentang pemerintah Daerah dan Undang-Undang Nomor 12 Tahun 2008 tentang perubahan kedua atas Undang-Undang Nomor 32 Tahun 2004 tentang pemerintah Daerah.

Ada perubahan yang sangat mendasar dalam undang-undang tentang pemerintahan daerah tersebut menggenai pemilihan kepala daerah. Meskipun dalam Pasal 18 ayat (4) tidak menentukan bahwa kepala daerah itu tidak mutlak dipilih secara langsung tetapi undang-undang tentang pemerintah daerah menentukan mengenai pemilihan haruslah secara langsung. Semangat demokrasi yang terdapat dalam

mempunyai pemerintahan daerah, yang diatur dengan undang-undang.

(2) Pemerintah daerah propinsi, daerah kabupaten, dan kota mengatur dan mengurus sendiri urusan pemerintahan menurut asas otonomi dan tugas pembantuan.

(3) Pemerintahan daerah propinsi, kabupaten, dan kota memiliki Dewan Perwakilan Rakyat Daerah yang anggota-anggotannya dipilih melalui pemilihan umum

(4) Gubernur, bupati, dan walikota masing-masing sebagai kepala pemerintahan daerah propinsi, kabupaten, dan kota dipilih secara demokratis.

5 Jimly Asshididiqie, Pokok-Pokok Hukum Tata Negara Indonesia, PT Bhuana Ilmu Populer, Jakarta, hlm,420 peraturan tersebut sehingga Kepala Daerah tidak lagi dipilih melalui DPRD melainkan langsung dipilih oleh rakyat seperti halnya pemilihan Presiden dan Wakil Presiden. Dari aspek yuridis ketatanegaraan gagasan pemilihan langsung Kepala daerah yang tertuang dalam UU No. 32 Tahun 2004 merupakan gagasan yang memberikan kesempatan yang luas kepada rakyat untuk memilih sendiri kepala daerahnya. Perubahan pemilihan kepala daerah dari DPRD ke pemilihan langsung oleh rakyat disebabkan adanya dugaan politik uang dalam proses pemilihan kepala daerah oleh DPRD.

Penggisian jabatan kepala pemerintahan dapat dilakukan dengan berbagai cara ada yang diangkat dengan cara pemilihan (elected public officials) dan ada yang diangkat tanpa pemilihan (non elected public officials).

Jabatan-jabatan yang diisi dengan cara pemilihan pada umunya adalah jabatan yang dikategorikan jabatan politik, sedangkat jabatan yang diisi dengan pengangkatan merupakan jabatan administratif. ${ }^{6}$ Jabatan yang diisi melalui pemilihan juga dapat dibedakan dalam beberapa kategori, yaitu pemilihan bersifat langsung oleh rakyat dan yang tidak langsung oleh rakyat. Ada juga jabatan yang diisi melalui pemilihan, tetapi bukan oleh rakyat, melainkan oleh badan-badan tertentu yang menjadi konstituen dari jabatan yang dipilih itu sendiri. Jabatan (ambt, functie, office),, dan pemegang jabatan atau pejabat itu (ambtsdrager, functionaires, official) dapat dibedakan dengan menggunakan jabatan negara dan jabatan negeri. ${ }^{7}$

\footnotetext{
${ }^{6}$ Ibid., hlm, 745

${ }^{7}$ Ibid.
} 
Pemegang jabatan negara disebut pejabat negara, sedangkan pemegang jabatan negeri disebut pejabat negeri. ${ }^{8}$ Pejabat negara adalah orang yang menduduki atau memegang jabatan publik melalui pemilihan yang bersifat politik atau melalui pengangkatan tetapi jabatanya itu sendiri bersifat politik, sedangkan pejabat negeri adalah pemegang jabatan publik melalui pengangkatan yang bersifat administratif. ${ }^{9}$ Jabatan presiden dan wakil presiden, gubernur dan wakil gubernur, bupati dan wakil bupati, serta walikota dan wakil walikota selaku kepala pemerintahan eksekutif merupakan jabatan politik yang harus dibedakan dari jabatan-jabatan yang bersifat teknis administratif.

Jabatan politik harus diisi melalui prosedur politik (politcal appointment), sedangkan jabatan adminstratif diisi menurut prosedur teknis administratif.

Dalam pengisian jabatan kepala daerah di Indonesia sudah pernah mengalami beberapa model pemilihan kepala daerah seiring dengan pergantian atau perubahan peraturan perundang-undangan tentang pemerintahan daerah. Undang-undang yang pernah berlaku di Indonesia seperti UU No. 1 Tahun 1945, UU No. 22 tahun 1948, UU No. 1 Tahun 1957, UU No. 18 Tahun 1965, UU No. 5 Tahun 1974, UU No. 22 Tahun 1999, UU No. 32 Tahun 2004 dan UU No. 12 Tahun 2008 tentang perubahan atas UU 32 Tahun 2004 maka dapat diklasifikasikan tata cara pemilihan kepala daerah yang pernah berlaku di Indonesia sebagai berikut:

1. Kepala daerah diangkat dan ditunjuk oleh pemerintah pusat

\footnotetext{
${ }^{8}$ Ibid.

${ }^{9}$ Ibid.
}

2. Kepala daerah dipilih oleh DPRD

3. Kepala daerah yang dipilih secara langsung

Sejak diberlakunnya UU No. 32 Tahun 2004 tentang Pemerintahan Daerah pada pertengahan tahun 2005, pengisian jabatan kepala daerah dan wakil kepala daerah dilakukan secara langsung. Perubahan paradigma dalam penyelenggaraan pemerintahaan daerah khususnya tata cara pemilihan kepala daerah secara langsung ini terjadi karena adanya perubahan dalam sistem ketatanegaraan kita yang lebih demokratis sehingga menghasilkan produk hukum yang responsif terhadap tuntutan-tuntutan baik individu maupun berbagai kelompok sosial di dalam masyarakat sehingga lebih mampu mencerminkan rasa keadilan di dalam masyarakat ${ }^{10}$

\footnotetext{
${ }^{10}$ Moh. Mahfud M.D. menjelaskan bahwa konfigurasi politik yang demokratis akan membuka peluang bagi berperannya potensi rakyat secara maksimal untuk turut aktif dalam menentukan kebijakan Negara dan produk hukum yang dihasilkan dari konfigurasi politik yang demokratis adalah produk hukum yang karakternya mencerminkan pemenuhan atas tuntutantuntutan baik individu maupun berbagai kelompok sosial di dalam masyarakat sehingga lebih mampu mencerminkan rasa keadilan di dalam masyarakat, sedangkan konfigurasi politik yang otoriter adalah konfigurasi politik yang menempatkan pemerintah pada posisi yang lebih dominant dengan sifat yang intervenvensionis dalam menentukan kebijakan Negara sehingga potensi dan aspirasi masyarakat tidak teragregasi dan terartikulasi secara proporsional, dan produk hukum yang dihasilkan bersifat konservatif/ortodoks yaitu produk hukum yang karakternya mencerminkan visi politik pemegang kekuasaan sangat dominant, sehingga proses pembuatan produk hukum tidak mengundang partisipasi dan aspirasi masyarakat secara sungguh-sungguh. Moh Mahfud MD, Pergulatan Politik dan Hukum
} 
Pemilihan umum kepala daerah (pemilukada) secara langsung yang diterapkan untuk mengisi jabatan kepala daerah dan wakil kepala daerah merupakan anti tesis dari tata cara pengisian jabatan kepala daerah sebelumnya dengan cara dipilih oleh DPRD dan pemilukada sejatinya ditujukan untuk memperdalam demokrasi atau perwujudan dari kedaulatan rakyat di Indonesia.

Pemilukada secara langsung menjadikan kepala daerah mempunyai legitimasi yang kuat akrena dipilih langsung oleh rakyat ada beberapa alasan diberlakukanya pemilukada secara langsung, pertama, pemilihan kepala dapat menciptakan suatu suasana dimana masyarakat mampu menilai arti dan manfaat sebuah pemerintahan; kedua, pemilihan dapat memberikan suksesi yang tertib dalam pemerintahan melalui transfer kewenangan yang damai kepada pemimpin yang baru ketika waktunya tiba bagi pemimpin lama melepaskan jabatanya, baik karena berhalangan tetap atau karena berakhirnya periode kepemimpinanya. ${ }^{11}$

Selanjutnya pemilukada secara langsung mempunyai tiga fungsi penting dalam penyelengaraan pemerintahan daerah, pertama, memilih kepala daerah sesuai dengan kehendak bersama masyarakat di daerah sehingga ia diharapkan dapat memahami dan mewujudkan kehendak masyarakat di daerah. Kedua, melalui pemilukada

Di Indonesia, Penerbit Gama Media, Yogyakarta, 1999.Hlm. 9

11 Sarundajang, Pemerintahan Daerah di berbagai negara, Tinjauan Khusus Pemerintahan Daerah di Indonesia: perkembangan kondisi dan tantangan, Jakarta; Sinar harapan, 2002, hlm. 165-166 diharapkan pilihan masyarakat di daerah didasarkan pada misi, visi, program serta kualitas dan intergritas kepala daerah, yang sangat menentukan keberhasilan penyelengaraan pemerintahan di daerah. Ketiga, pemilukada merupakan sarana pertanggungjawaban sekaligus sarana evaluasi dan kontrol publik secara politik terhadap seorang kepala daerah dan kekuatan politik yang menopang. ${ }^{12}$

Pengisian jabatan kepala daerah melalui pemilukada selain berdasarkan UU No. 32 Tahun 2004 ada bebebarapa peraturan pelaksana lainya sebagai berikut:

a. UU No. 8 Tahun 2005 tentang Penerapan Peraturan Peraturan Pemerintah Pengganti UU No 3 Tahun 2005 tentang Perubahan atas UU No. 32 Tahun 2004 tengtang Pemerintahan Daerah

b. UU No. 12 Tahun 2008 tentang Perubahan kedua atas UU No. 32 tahun 2004 tentang Pemerintahn Daerah

c. UU No. 22 Tahun 2007 tentang Penyelenggaraan Pemilihan Umum yang dirubah menjadi UU No. 15 Tahun 20011 tentang Penyelenggaraan Pemilihan Umum

d. Peraturan Pemerintah No. 6 Tahun 2005 tentang pemilihan, Pengesahan, Pengangkatan dan Pemberhentian Kepala Daerah, dan Wakil Kepala Daerah

e. Peraturan Pemerintah No. 17 Tahun 2005 tentang Perubahan atas Peraturan Pemerintah No. 6 Tahun 2005 tentang Pemilihan, Pengesahan Pengangkatan, dan

12 Jenedjri M. Gaffar, Politik Hukum Pemilu, Konstitusi Prss, Jakarta, 2012, hlm,85 
Pemberhentian Kepala Daerah, dan Wakil Kepala Daerah

f. Peraturan Pemerintah No. 25

Tahun 2007 tentang Perubahan

Kedua atas Peraturan Pemerinta

No. 6 Tahun 2005 tentang

Pemilihan, Pengesahan,

Pengangkatan, dan

Pemberhentian Kepala Daerah, dan Wakil Kepala Daerah

g. Peraturan Pemerintah No 49 tahun 2008 tentang perubahan ketiga atas Peraturan Pemerinta No. 6 Tahun 2005 tentang Pemilihan, Pengesahan, pengangkatan, dan Pemberhentian Kepala daerah dan Wakil Kepala Daerah.

Pemilukada yang dilakukan sejak tahun 2005, dari tujuh tahun pengalaman pemilukada langsung ini, peristiwa tersebut justru menimbulkan dampak negatif dalam kehidupan berdemokrasi. Dalam prakteknya, pemilukada langsung telah menyuburkan praktek politik uang, dari berupa biaya yang dikeluarkan oleh calon kepala daerah dan wakil kepala daerah bagi partai politik pengusung calon kepala daerah, biaya fotokopi KTP untuk syarat dukungan calon perseorangan, biaya penyelenggaraan pemilukada yang memerlukan biaya yang cukup besar, serta adanya dugaan pemakaian dana APBD untuk kepentingan calon kepala daerah yang sedang menjabat (incumbent). Yang paling sangat memperhatinkan adalah terjadinya konflik horizontal antara pendukung calon kepala daerah yang kalah dalam pemilihan dengan pendukung calon kepala daerah yang menang dalam pemilihan serta adanya tindakan anarkis yang dilakukan oleh pendukung calon kepala daerah dengan melakukan pengrusakan berbagai fasilitas umum dan perkantoran milik pemeritah.

Selain permasalahanpermasalahan tersebut di atas, pemilukada secara langsung yang diharapkan menghasilkan pemimpinpemimpin daerah yang mempunyai intergritas dimana mampu memimpin penyelenggaraan pemerintahan di daerahnya sehingga dapat menciptakan kesejahteraan rakyatnya sebagaimana tujuan dari otonomi daerah justru para kepala daerah yang dipilih melalui pemilukada secara langsung banyak tersangkut persoalan hukum (korupsi) baik kepala daerah yang sudah tidak menjabat lagi atau yang masih menjabat sebagai kepala daerah.

Penangkapan oleh Komisi Pemberantasan Korupsi atas Bupati Buol Amran Batalipu akibat dugaan suap telah memperpanjang daftar kepala daerah yang tersangkut persoalan hukum, karena tuntutan dana yang besar untuk memenangi pemilukada langsung di daerahnya.

Berdasarkan permasalahanpermasalahan yang muncul dalam pemilihan Kepala Daerah secara demokratis tersebut, Undang-Undang Nomor 32 tahun 2004 tentang Pemeritahan Daerah merupakan undang-undang yang mengatur secara gamblang tentang Pemerintahan Daerah.

Terkait dengan UU ini saat ini sedang hangat diperbincangkan tentang pemilihan kepala daerah yang ingin mengembalikan tata cara pemilhan kepala daerah secara langsung menjadi pemilihan kepala daerah oleh DPRD". Jika dikaitkan dengan demokrasi yang mana pemerintahan dari rakyat, oleh rakyat, dan untuk rakyat. 
Pemahaman sederhana yang dapat digambarkan atas sebuah demokrasi. Demokrasi ini dituangkan dalam Pasal 1 ayat (2) Undang-Undang Dasar Negara Republik Indonesia tahun 1945 (UUD NRI 1945), yaitu "kedaulatan berada di tangan rakyat dan dilaksanakan menurut UndangUndang”.

\section{Pembahasan}

2.1.Pengisian Jabatan Kepala Daerah dalam Peraturan PerundangUndangan tentang Pemerintahan Daerah.

Dalam menyelenggarakan pemerintahan daerah terdapat unsur pimpinan dan perangkat daerah untuk menyelenggarakan pemerintahan. Kepala daerah salah satu unsur tersebut, Pengisian jabatan kepala daerah semenjak Indonesia merdeka hingga kini selalu berubah mengikuti dinamika yang terjadi di masyarakat. Kepala daerah memiliki peran yang signifikan untuk suksesnya tujuan negara melalui tugas dan kewenangannya yang telah di atur dalam undang-undang. Pengisian jabatan kepala daerah dapat kita lihat dalam peraturan perundang-undangan yang pernah ada dan masih berlaku di Indonesia.

\section{UU No. 1 Tahun 1945}

Undang-undang ini diterbitkan pada tanggal 23 November 1945. UU No 1 Tahun 1945 tentang Komite Nasional Daerah yang didalamnya mengatur tentang pengisian jabatan kepala daerah melalui pemilihan oleh Komite Nasional Daerah, dimana komite ini memilih sebanyak 5 (lima) orang diantara anggotanya duduk di Badan Eksekutif yang salah satunya menjadi Kepala Daerah yang bertindak sebagai ketua sekaligus anggota. Berdasarkan uraian tersebut, pemilihan kepala daerah menurut UU No. 1 Tahun 1945 adalah pemilihan kepala daerah melalui sistem perwakilan ini sesuai dengan Pasal 1 Ayat 2 UUD 1945 dimana pelaksanaan kedaulatan rakyat melalui badab perwakilan (MPR) dalam hal ini didaerah adalah Komite Nasional Daerah.

\section{UU No. 22 Tahun 1948}

UU No. 22 Tahun 1948 dilahirkan dalam suasana sistem pemerintahan parlementer dimana menteri-menteri tifdak bertanggungjawab kepada Presiden tetapi bertanggungjawab kepada Komite Nasional Indonesia Pusat (KNIP). UU No 22 Tahun 1948 merupakan produk hukum berupa UU pertama yang mengatur secara khusus tentang Undang-Undang Pokok Pemerintahan Daerah. Tentang pengisian jabatan kepala daerah Propinsi (Gubernur) diangkat oleh Presiden yang diajukan oleh DPRD Propinsi dan kepala daerah kabupaten diangkat oleh Menteri Dalam Negeri dari calon yang diajukan oleh DPRD kabupaten.

Meskipun UU No. 22 tahun 1945 sudah lebih rinci dibandingkan UU No. 1 Tahun 1945 tentang Pengaturan jabatan kepala daerah, tetapi kewenangan daerah melalui DPRD sebatas mengusulkan calon, kewenangan pengangkatan usulan calon kepala daerah mutlak menjadi kewenangan pemerintah pusat. Prinsip kedaulatan rakyat tidak tercermin dalam UU No. 22 Tahun 1948 dalam pemilihan kepala daerah dimana kepala daerah diangkat oleh 
Pemerintah Pusat dalam hal ini Presiden dan MenterI Dalam Negeri.

\section{UU No. 1 Tahun 1957}

Undang-undang ini diterbitkan setelah pelaksanaan pemilihan umum 1955. UU No 1 Tahun 1957 pengisian jabatan kepala daerah untuk sementara waktu dipilih oleh DPRD dari calon-calon yang memenuhi persyaratan kecakapan dan pengetahuan yang diperlukan bagi jabatan tersebut yang diatur dengan peraturan pemerintah. Untuk selanjutnya hasil pemilihan tersebut mendapat pengesahan dari pemerintah pusat. Tidak dilaksanakanya pemilihan kepala daerah secara lansung walaupun dalam UU tersebut telah ada wacana pemilihan kepala daerah secara langsung tetapi melihat kondisi sosial dan politik pada saat itu belum memungkinkan untuk diwujudkan sehingga UU yang mengatur secara khusus tentang pemilihan secara lansung tidak pernah diterbitkan. ${ }^{13}$

Pengisian jabatan kepala daerah menurut UU No. 1957 telah memenuhi prinsip Kedaulatan rakyat sesuai dengan ketentuan yang tertuang dalam konstitusi yang berlaku saat itu yaitu Pasal 1 Ayat 2 UUDS RI No. Tahun 1950: "Kedaulatan Republik Indonesia adalah ditangan rakyat dan dilakukan oleh pemerintah bersama-sama dengan Dewan Perwakilan Rakyat"

\section{Penetapan Presiden (Penpress) No. 6 Tahun 1959}

\footnotetext{
Adanya perubahan sistem poltik dan pemerintah dengan

13 Wendy melfa, Pemilukada (Demokrasi dan Otonomi Daerah), BE Press, Lampung, 2013, hlm, 124
}

dilkeluarkanya Dekrit Presiden tanggal 5 Juli 1959 telah menyebabkan berakhirnya masa keberlakuan UU No. 1 Tahun 1957 tentang Pokok-Pokok Pemerintahan Daerah dirubah dan diganti dengan Penetapan Presiden (Penpres) No. 6 Tahun 1959 tentang Pemerintahan Daerah. Perubahan yang paling mendasar melalui Penpress ini adalah adanya hak prerogatif Presiden dan Menteri Dalam Negeri untuk mengangkat Kepala daerah. ${ }^{14}$

\section{UU No. 18 Tahun 1965}

UU No. 18 Tahun 1965 tentang Pokok-Pokok Pemerintahan Daerah dikeluarkan setelah dikelurkanya Dekrit Presiden 5 Juli 1959.

UU No. 18 tahun 1965 dalam hal pengisian jabatan kepala daerah hampr seluruhnya meneruskan, memindahkan atau menjabarka lebih lanjut ketentuan-ketentuan yang ada pada Penpres No. 6 tahun 1959. Dapat disimpulkan pengisian jabatan kepala daerah berdasarkan UU No. 18 Tahun 1965 tidak dapat diketegorikan dalam pelaksanaan kedaulatan rakyat. Ketentuan pengisian jabatan kepala daerah dalam UU tersebut bertentangan dengan UUD 1945 Pasal 1 Ayat 2 .

\section{UU No. 5 Tahun 1974.}

UU No. 5 Tahun 1974 tentang Pokok-Pokok Pemerintah Daerah dalam hal pengisian jabatan kepala daerah dimana pengankatan kepala daerah untuk Dati I oleh Presiden dan Dati II oleh Menteri Dalam Negeri dari minimal 2 calon yang dipilih oleh DPRD. Presiden dan Menteri Dalam Negeri tidak terikat

${ }^{14}$ Ibid., hlm. 127 
pada peringakt hasil pemilihan yang dilakukan oleh DPRD, sebab akhir peneotapan merupakan Hak Prerogatif dari Presiden atau Menteri dalam Negeri. Adanya kewenangan pemerintah Pusat dalam untuk mengangkat kepala daerah tanpa terikat dengan hasil pemilihan yang dilakukan oleh DPRD tidak mencerminkan pelaksanaan kedaulatan rakyat

\section{Undang-Undang Nomor 22 Tahun 1999}

UU No. 22 Tahun 1999 tentang Pemerintahan daerah merupakan mmomentum sejarah dalam perkembangan penyelenggaran pemerintahan daerah. Terkait pengisian jabatan kepala daerah. Menurut Undang-Undang Nomor 22 Tahun 1999 tentang pemerintah daerah menganut sistem pemilihan tidak langsung yakni para kepala daerah di pilih oleh Dewan Perwakilan Rakyat Daerah (DPRD).

Dalam pasal 34 ayat (1) pengisian jabatan kepala daerah dan wakil kepala daerah, dilakukan oleh DPRD melalui pemilihan secara bersamaan, (2) calon kepala daerah dan wakil calon kepala daerah, ditetapkan oleh DPRD melalui tahap pencalonan dan pemilihan.

Dalam Undang-Undang ini, pemilihan kepala daerah dipilih oleh DPRD, pelaksanaan kedaulatan rakyat menurut undang-undang ini dilakukan secara tidak langsung atau demokrasi perwakilan. panitia pemilihanpun berasal dari DPRD, pencalonan dan penyaringan calon juga di lakukan oleh DPRD melalui partai politik yang memiliki kursi di DPRD yang membentuk suatu fraksi- fraksi dengan syarat-syarat tertentu, dengan sistem ini masyarakat hanya bisa memantau dan mengawasi serta mencalonkan calon kepala daerahnya melalui DPRD sebagai perwakilannya.

\section{Undang-Undang Nomor 32 Tahun 2004 dan Undang-Undang Nomor 12 Tahun 2008 tentang Pemerintah Daerah}

Menurut Undang-Undang Nomor 32 Tahun 2004 tentang pemerintah daerah jo UndangUndang-Undang Nomor 12 Tahun 2008 tentang perubahan kedua atas Undang-Undang Nomor 32 Tahun 2004 tentang pemerintah daerah, pemilihan kepala daerah di lakukan secara langsung dengan menggunakan sistem pemilihan langsung yang memberi kesempatan seluas-luasnya kepada rakyat untuk memilih sendiri kepala daerah dan wakil kepala daerahnya.

Sebelum adanya judicial review ke Mahkamah Konstitusi yang dapat mencalonkan kepala daerah dan wakil kepala daerah hanyalah diajukan oleh partai politik dan gabungan partai politik, kemudian Mahkamah Konstitusi mengabulkan permohonan pemohon bahwa calon perseorangan atau independent bisa ikut serta pemilihan umum kepala daerah sesuai persyaratan tertentu, hal inilah yang mendorong di lakukannya legislative review terhadap Undang-Undang Nomor 32 Tahun 2004 di rubah menjadi Undang Nomor 12 Tahun 2008. 


\subsection{Pengisian Jabatan Kepala Daerah}

Pengisian jabatan kepala daerah adalah sebuah tata cara dalam mewujudkan kedaulatan rakyat. Pasal 18 Ayat 4 UUD 1945 amandemen II berbunyi: "Gubernur, Bupati, dan walikota masing-masing sebagai kepala pemerintahan daerah propinsi, kabupaten, dan kota dipilih secara demokratis." Ketentuan ini menjadi landasan konstitusional dalam pengisian jabatan kepala daerah sejak disahkanya perubahan II UUD 1945 tanggal 18 Agustus Tahun 2000 dalam suatu sidang Majelis Permusyawaratan Rakyat.

Terhadap ketentuan Pasal 18 Ayat 4 UUD 1945 yang merupakan landasan konstitusional pengisian jabatan kepala daerah tidak disebutkan secara tegas tentang bagaimana cara berkedaulatan rakyat yang digariskan oleh konstitusi negara dalam menentukan pengisian jabatan kepala daerah, apakah dengan demokrasi langsung (direct democracy) atau demokrasi perwakilan (reprecentativ democracy).

Pasal 18 Ayat 4 hanya memberikan syarat bahwa pengisian jabatan kepala daerah bersifat demokratis. Pengertian demokratis menimbulkan dua pandangan dalam menentukan pengisian jabatan kepala daerah, dapat dengan cara demokrasi langsung, atau melalui demokrasi perwakilan juga dikatakan sebagai cara yang demokratis untuk memilih kepala daerah.

Menurut Jimly Asshidddiqie, pengertian demokratis di dalam pemilihan kepala daerah dapat dilaksanakan dengan cara pemilihan langsung maupun dengan cara perwakilan (pemilihan oleh DPRD). ${ }^{15}$

Dalam proses pembahasan ketentuan pengisian jabatan kepala daerah, terdapat dua pandangan yang bebeda. ${ }^{16}$ Pendapat pertama mengusulkan agar pemilukada dilakukan secara langsung oleh rakyat, tidak melalui sistem perwakilan oleh DPRD ${ }^{17}$. Pendapat kedua menghendaki pemilukada tetap dilakukan oleh DPRD.${ }^{18}$ Kesepakatan rumusan "secara demokratis" untuk pemilukada dicapai dengan maksud agar bersifat fleksibel. Pembuat undang-undang dapat menentukan sistem pemilukada yang sesuai dengan dengan kondisi daerah tertentu apakah secara langsung atau melalui perwakilan DPRD ${ }^{19}$ hal ini juga dimaksudkan sebagai bentuk penghargaan konstitusi terhadap keragaman adat istiadat dan budaya masyarakat antar daerah yang berbeda. $^{20}$

Pratek pengisian jabatan kepala daerah melalui pemilihan dengan cara perwakilan (reprecentativ democracy) berdasarkan Pasal 18 Ayat (4) UUD 1945 pernah dilakukan dengan UU No. 22 Tahun 1999 tentang Pemerintahan Daerah dimana kepala daerah dipilih oleh DPRD.

Sistem perwakilan dalam pemilihan kepala daerah yang dilakukan berdasarkan UU No. 22 Tahun 1999 tentang Pemerintahan Daerah telah dianggap gagal untuk menjalankan amanat konstitusi

\footnotetext{
15 Jimly Asshiddiqie, Komentar Atas Undang-Undang Dasar 1945, Rajagrafindo, Jakarta, hlm, 58-59

${ }^{16}$ Jenedjri M. Gaffar, Op.Cit, hlm 93.

${ }^{17}$ Ibid.

${ }^{18}$ Ibid.

${ }^{19}$ Ibid., hlm 94

${ }^{20}$ Ibid.
} 
dalam mewujudkan kedaulatan rakyat dalam pratek ketatanegaraan. Sistem perwakilan dalam pemilihan kepala daerah sangat rentan terjadi tawar menawar, politik uang, intervensi politik, dan berbagai penyimpangan lainnya. Disisi lain dengan pengisian jabatan kepala daerah melalui sistem perwakilan menyebakan posisi DPRD lebih kuat dari kepala daerah, karena kepala daerah juga bertanggung jawab kepada DPRD sebagai konsekuensi kepala daerah dipilih oleh DPRD.

Berdasarkan uraian tersebut UU NO. 22 Tahun 1999 diganti dengan UU No. 22 Tahun 2004 tentang Pemerintahan Daerah. Undang-Undang Nomor 32 tahun 2004 tentang Pemerintahan daerah merupakan Undang-Undang yang mengatur secara gamblang tentang Pemerintahan Daerah terutama pengisian jabatan kepala daerah dan wakil kepala daerah secara langsung oleh rakyat bukan melalui perwakilan di DPRD.

Munculnya gagasan pengisian jabatan kepala daerah melalui pemilihan secara langsung merupakan langkah perbaikan pembentuk undang-undang terhadap tata cara demokrasi perwakilan yang diterapkan oleh UU No. 22 Tahun 1999. Dimana pengisian jabatan kepala daerah melalui pemilihan secara langsung oleh rakyat diharapkan dapat menjadi media pergantian kepemimpinan politik di daerah. Pemilukada secara langsung dapat melahirkan kepala daerah terpilih berkualitas, aspiratif, dan legitimate yang akan lebih meningkatkan pembangunan dan kesejahteraan masyarakat karena pemimpin dan pemerintahnya dekat dengan rakyat.
Awal penerapannya tata cara pemilukada mendapakan sambutan yang tinggi dari masyarakat. Sambutan yang tinggi dari masyarakat ditunjukan dengan tingkat partisipasi masyarakat yang tinggi dari setiap penyelenggaran pemilukada. Partipasi yang tinggi dari masyarakat merupakan salah satu ukuran keberhasilan penyelenggaran pemilukada, termasuk legitimasi calon kepala daerah terpilih. $^{21}$

Selanjutnya penyelenggaran pemilukada tingkat partisifasi masyarakat yang semakin menurun atau berkurang, menurut Mahfud ada 4 (empat) penyebab turunya partisifasi masyarakat terhadap penyelenggaraan Pemilukada ${ }^{22}$ :

Pertama, masyarakat secara sadar memang tak mau menggunkan hak pilihnya karena dilandasi sikap apatis. Bagi mereka menggunakan atau tidak menggunakan hak suaranya tidak memberikan pengaruh signifikan dalam keseharian hidupnya. Kedua, Daftar Pemilih Tetap (DPT) yang amburadul dan tidak akurat berkontribusi besar melemahkan semangat masyrakat yang semula berniat untuk berpartisipasi, Ketiga, masyarakat pemilih cenderung mendahulukan kebutuhan individunya seperti berkerja, berladang, merantua, ketimbang hadir ke TPS dalam mengunakan hak pilihnya, keempat, partisipasi dalam pemilukada didorong semangat pragmatism masyarakat, kalau ada kandidat yang memberi keuntungan mereka mau berpartisifasi, kalau tidak maka tidak perlu berpartisifasi.

21 Moh. Mahfud MD, Demokrasi Lokal, Evaluasi Pemilukada di Indonesia, Konstitusi Press, Jakarta, 2012, hlm. 8

${ }^{22}$ Ibid. 
Setelah proses percepatan demokrasi secara beruntun tersebut berjalan kurang lebih lima tahun terhitung 1 Juni 2005, ternyata masih menyisakan banyak persoalan, bahkan agenda pemilihan kepala daerah secara langsung pun juga berkontribusi menambah beban politik, sosial bahkan beban finansial republik ini. Pemilihan kepala daerah secara langsung terlalu boros, dan tidak seimbang dengan cost politik yang telah dikorbankannya. Pemilukada langsung yang mengusung calon kepala daerah/wakil secara berpasangan ternyata juga tidak sepenuhnya mampu menghadirkan pemimpin daerah yang baik dan bermoral.

Pemilukada sebagai sebuah perwujudan demokrasi terutama prinsip kedaulatan rakyat dalam pemerintahan daerah, diharapakan dapat menciptakan kedewasan berdemokrasi dimasyarakat.

Implementasi pelaksanaan pemilukada dilapangan masih menunjukan adanya fenomena yang merusak pemilukada itu sendiri, seperti money politik, ketidakanetralan aparatur (birokrasi pemerintah daerah) penyelenggara pemilukada (KPUD), kecurangan berupa pelanggaran kampanye dan pengelembungan suara, serta penyampaian pesan-pesan poliotik yang bernuansa sektarian yang berujung retaknya bingkai kehidupan berbangsa yang dibangun berdasar prinsip Bhineka Tunggal Ika.

Pada sisi lain ketidaksiapan dan ketidakdewasaan para kandidat dan pendukung untuk mensyukuri kemengan dan menerima kekalahan yang sering diwujudkan dengan bentuk-bentuk anarkis telah menimbulkan konflik di berbagai daerah.

Banyaknya permasalahan dalam pemilukada langsung menjadi salah satu alasan mengapa UndangUndang Nomor 32 Tahun 2004 tentang Pemerintahan Daerah, Pemerintah telah mengusulkan koreksi terhadap sistem pemilukada langsung, di antaranya pemilihan gubernur kembali dilakukan oleh DPRD provinsi, sementara itu pemilihan bupati/wali kota tetap secara langsung oleh masyarakat. Di samping itu, wakil kepala daerah tidak lagi dipilih secara berpasangan dengan kepala daerah, untuk menghindari fenomena "pecah kongsi" yang mengakibatkan tidak efektifnya penyelenggaraan pemerintahan daerah.

Indonesia melalui konstitusinya menegaskan sebagi sebuah negara demokratis Pasal Ayat 2 UUD 1945 : “ Kedaulatan berada di tangan rakyat dan dilaksanakan menurut undang-undang dasar". Kedaulatan rakyat atau kerakyatan secara harfiah berarti kekuasaan tertinggi ada pada rakyat. Negara yang menempatkan kekuasaan tertingi pada rakyat, disebut sebagi Negara demokratis yang sering diartikan atau digambarkan sebagai pemerintahan dari rakyat, oleh rakyat, dan untuk rakyat. Dari rakyat, maksudnya bahwa mereka yang duduk sebagi penyelenggara Negara atau pemerintah harus terdiri dari seluruh rakyat itu sendiri atau yang disetujui oleh atau didukung oleh rakyat. ${ }^{23}$ Oleh rakyat maksudnya penyelenggara Negara

23 Bagir Manan dan Kuntana Magnar, Mewujudkan Kedaulatan Rakyat Melalui Pemilihan Umum, Kedaulatan Rakyat, Hak Asasi Manusia dan Negara Hukum, Gaya Media Pratama, Jakarta, 1996, hlm, 56 
atau penyelenggara pemerintah, dilakukan sendiri oleh rakyat atau anas nama rakyat atau yang mewakili rakyat. $^{24}$

Dengan demikian dapat dipahami dalam sebuah Negara demokratis rakyatlah sesungguhnya pemilik Negara dengan segala kewenanganya untuk menjalankan fungsi kekuasaan Negara, baik dibidang legislatif, eksekutif, maupun yudikatif.

Lembaga-lembag Negara yang melaksanakan fungsi kekuasaan Negara dianggap melaksankan kedaulatan rakyat. berdasarkan undang-undang dasar. Gagasan demokrasi langsung adalah gagasan pentingnya partispasi masyarakat secara luas tentang proses pembuatan keputusan atau kebijakan dan pelaksanaan keputusan atau kebijakan yang dibuat oleh wakil wakil yang memiliki otoritas.

Pelaksanaan pemilihan langsung kepala daerah merupakan koreksi atas penyelenggara pemilihan kepala daerah oleh DPRD berdasarkan UU No. 22 tahun 1999 yang diganti dengan UU No. 32 Tahun 2004 tentang Pemerintah Daerah sebagai landasan yuridis pelaksanaan Pengisian jabatan Kepala daerah melalui pemilihan kepala daerah secara langsung. Penerapan demokrasi langsung dalam pengisian jabatan kepala daerah ini didasarkan atas Pasal 18 Ayat 4 UUD 1945 yang tidak secara tegas dalam menentukan tata cara pengisian jabatan kepala daerah apakah mengunakan demokrasi langsung atau demokrasi perwakilan.

Otonomi daerah dipahami sebagai hak, wewenang dan kewajiban daerah otonom untuk

${ }^{24}$ Ibid. mengatur dan mengurus sendiri urusan pemerintahan dan kepentingan masyarakat setempat sesuai dengan peraturan perundangundangan.

Cara mengatur dan mengurus atau menentukan nasib sendiri berkaitan erat dengan pelaksanaan kedaulatan rakyat dalam hal ini perwujudan kedaulatan rakyat di daerah salah satunya adalah pemilihan langsung kepala daerah. Pelaksanaan pemilukada banyak menimbulkan permasalah seperti yang ditelah diuraikan di atas karena itu ada keinginan untuk mengembalikan pemilihan kepala daerah oleh DPRD. Dapat dipahami bahwa perubahan yang dilkukan dalam tata cara pemilihan kepala daerah dilandasi oleh semangat untuk memperbaiki dan menciptakan situasi yang lebih baik sesuai dengan harapan terpilihnya kepala daerah yang berkualitas, aspiratif dan bermoral. Tetapi mengembalikan atau merubah tata cara pemilihan kepala daerah oleh DPRD bukanlah cara yang tepat.

Pemilihan oleh DPRD tidak menjamin dapat mengurangi ongkos politik calon kepala daerah dan meniadakan politik uang dalam pemilihan kepala daerah serta menghilangkan pratek korupsi kepala daerah. Menurut Jenedjri M. Gafarr Frasa " secara demokratis" dalam Pasal 18 Ayat 4 UUD 1945 pemilihan kepala daerah dapat dilakukan secara langsung atau melalui perwakilan keduanya, asalkan dilakukan secara jujur dan adil serta sesuai dengan prinsipprinsip pemilihan, adalah cara yang demokratis. $^{25}$ Menurut penulis pemilihan secara langsung oleh

${ }^{25}$ Jenedjri M. Gaffar, Op Cit hlm, 95 
rakyat lebih demokratis karena melibatkan seluruh rakyat sehingga dapat menghasilkan pemimpin yang mempunyai legitimasi yang kuat daripada kepala daerah yang dipilih oleh DPRD.

Ketentuan Frasa "secara demokratis" yang ditafsirkan pemilihan kepala daerah dapat secara langsung atau melalui perwakilan DPRD menimbulkan ketidakpastian dalam menerapkan model pengisian jabatan kepala daerah. ketentuan pengisian jabatan kepala daerah seharusnya lebih tegas seperti ketentuan dalam hal pengisian jabatan presiden dan wakil presiden dimana dalam Pasal 6A Ayat I UUD 1945 : Presiden dan Wakil Presiden dipilih dalam satu pasangan secara langsung oleh rakyat". Ketentuan ini lebih tegas sehingga tidak menimbulkan banyak penafsiran dan perdebatan.

Sebagai landasan pemilukada alangkah lebih baik ketentuan pasal 18 Ayat 4 mengikuti ketentuan dalam pemilihan Presiden dan Wakil Presiden karena landasan filosofis pelaksanaan pemilihan Presiden dan Wakil Presiden mempunyai kesamaan dengan pemilihan kepala daerah yakni pelaksanaan kedaulatan rakyat sesuai dengan Pasal 1 Ayat 2 UUD 1945 , yang membedakan hanya ruang lingkup yakni tingkatan nasional dan daerah. ${ }^{26}$

Sejak penerapan pemilukada berdasarkan UU No. 32 Tahun 2004 tentang Pemerintahan Daerah, masih banyak permasalahan yang perlu adanya perbaikan dalam hal penyelengaaran pemilukada evaluasi dan perdebatan publik dalam kerangka koreksi terhadap sistem penyelenggaran pemilukada yang

${ }^{26}$ Wendy Melfa, Op Cit., hlm. 228. penuh dengan permasalahanya memberikan masukan kepada pembuat undang-undang dapat menilai,memilih serta memutuskan kebijakan yang tepat dalam merumuskan tata cara yang tepat dalam penyeleggaraan pemilukada.

Penyelenggaran pemillukada yang selama ini dilakukan sudah berada dijalan yang tepat sebagai sebuah penerapaan nilai-nilai demokrasi dalam hal ini kedaulatan rakyat dalam penyelenggaran pemerintahan. Demokrasi yang sedang kita laksanakan sekarang ini (pemilukada) memberikn peluang kebebasan mengekspresikan aspirasi dan kehendak perseorangan atau kelompok. Pemilukada dalam tataran demokratisasi ditingkat lokal merupakan konsekuensi dari pelaksanaan desentralisasi politik. Bahwa penyelenggaraan pemulukada banyak menimbulkan permasalahan bukan berati harus mengembalikan ke sistem semula yang pernah dianggap gagal dalam pelaksanaanya (pemilihan oleh DPRD).

Perbaikan Penyelenggaran pemilukada harus memperhatikan berbagai aspek yakni dari aspek peraturan perundang-undang yang yang menjadi landasan hukumnya, aspek tingkat kesiapan pelaksanaan terutama penyelenggara pemilu dalam hal ini KPU dan Bawaslu kedua lembaga ini harus diperkuat terutama dalam proses rekrumen calon anggota KPU dan Bawaslu sehingga dapat menghasilkan anggota KPU dan Bawaslu yang dapat dipercaya sehingga menghasilkan kwalitas Pemilukada yang legitimate, selanjutanya aspek kondisi sosial masyarakat. Berdasarkan hal tersebut dapat dilihat dari segi mana yang paling banyak kekurangan yang perlu 
perbaikan dalam penyelenggaran pemilkuda.

Pemilukada sebagai sebuah media dalam tata pemerintahan kita yang menjadi penentu keberhasilan sebuah demokrasi di daerah. keberhasilan sebuah demokrasi di daerah mencerminkan keberhasilan demokrasi di tingkat naisonal. Sekaligus sebagai penentu kualitas sosok kepala daerah. tujuan utama kita menjalankan kehidupan berbangsa dan bernegara dengan sistem demokrasi yang kita anut, tiada lain adalah dalam rangka mewujudkan kesejahteraan masyarakat melalui pemerataan dan perumbuhan ekonomi, walaupun pratek demokrasi itu sendir sering menghadirkan berbagai tantangan dan permasalahan (pemilukada).

\section{Simpulan}

Berdasarkan Pasal 18 Ayat 4 UUD 1945, Penyelenggaran Pemilukada dapat dilakukan secara langsung atau melalui perwakilan oleh DPRD. Ketentuan ini menyebabkan adanya ketidakpastian dalam menentukan model pengisian jabatan kepala daerah semestinya Undang-Undang Dasar memberikan ketentuan yang tegas seperti tata cara pemilihan presiden dan wakil Presiden secara atau sesuai atau sejalan dengan Pasal 1 Ayat 2 UUD 1945 dimana prisip kedaulatan rakyat dengan sistem pemilihan langsung

\section{Daftar Pustaka}

Bagir Manan dan Kuntana Magnar, Mewujudkan Kedaulatan Rakyat Melalui Pemilihan Umum, Kedaulatan Rakyat, Hak Asasi Manusia dan Negara Hukum, Gaya Media Pratama, Jakarta, 1996,

Jimly Asshiddiqie, Komentar Atas Undang-Undang Dasar 1945, Rajagrafindo, Jakarta, 2009

Hukum Tatar Negara
Indonesia, PT Bhuana Ilmu
Populer, Jakarta, 2007
Jenedjri M. Gaffar, Politik Hukum Pemilu, Konstitusi Press, Jakarta, 2012,

M. Laica Marjuki, Berjalan -Jalan di Ranah Hukum: Otonomi Daerah Dalam Perspektif Negara Kesatuan, Penerbit Sekretariat Jenderal \& Kepaniteraan Makamah Konstitusi RI, 2006.

Moh. Mahfud MD, Demokrasi Lokal, Evaluasi Pemilukada di Indonesia, Konstitusi Press, Jakarta, 2012,

Sarundajang, Pemerintahan Daerah di berbagai negara, Tinjauan Khusus Pemerintahan Daerah di Indonesia: perkembangan kondisi dan tantangan, Jakarta; Sinar harapan, 2002,

Wendy Melfa, Pemilukada (Demokrasi dan Otonomi Daerah), BE Press, Lampung, 2013. 